XXVII Cangressa de Iniciaçãa Científica Unicamp

16 a 18 de outubro de 2019 - Campinas | Brasil

\title{
Relações bilaterais de comércio entre Estados Unidos e China (1995-2018)
}

\section{Gabriele R. Foschini ${ }^{\star}$, Giuliano Contento de Oliveira.}

\section{Resumo}

O trabalho tem o objetivo de analisar as relações bilaterais de comércio entre os Estados Unidos e a China. A análise das relações de comércio entre esses dois países, tanto do ponto de vista dos volumes exportados e importados como do perfil do comércio bilateral por intensidade tecnológica dos produtos negociados, constitui passo importante para compreender a atual guerra comercial e suas implicações nas relações comerciais atuais e futuras entre os dois países. O trabalho foi realizado a partir de revisão bibliográfica e da análise de dados e indicadores selecionados de comércio, com base nos dados UnctadStat, entre 1995 e 2018.

\section{Palavras-chave:}

Comércio, China, Estados Unidos.

\section{Introdução}

A partir da década de 1990, foi observado um maior acirramento das relações entre os Estados Unidos e a China, principalmente pelo aprofundamento da abertura comercial deste país, em 1992. O crescimento econômico vigoroso registrado na China foi acompanhado pela expressiva expansão das exportações, o que fez com que o país receber parte relevante dos fluxos de Investimentos Estrangeiros Diretos (IED) globais, com destaque para os investimentos greenfield, "criando uma interdependência produtiva com a abertura de filiais e joint-ventures". Esse processo resultou na atração das atividades produtivas de vários países para o seu território, gerando o aumento de suas exportações, principalmente para os Estados Unidos. Durante esse processo, foi construída uma relação de complementaridade das cadeias produtivas entre esses dois países, na qual a China foi a grande importadora de tecnologia, bens de capital e insumos dos EUA, o qual é, por sua vez, o principal destino das exportações de manufaturados chineses. Atualmente, é inegável a conclusão de que os países apresentam economias com grande interdependência, porém é necessario ressaltar que essa relação se insere em um novo contexto no período mais recente.

\section{Resultados e Discussão}

Após a crise financeira global de 2008, ocorreu a exacerbação do protecionismo comercial e o aumento da competição internacional, sendo esse contexto bastante ilustrado nas eleições americanas de 2016 em que Donald Trump foi eleito. Os Estados Unidos e a China são duas grandes potências comerciais em âmbito global e têm vivenciado uma relação instável, devido à presença simultânea de um sentimento de cooperação e de concorrência, o que vem chamando a atenção mundial.

A manutenção da relação de cooperação se tornou uma tarefa difícil, não apenas devido ao sentimento "anti-China" de Trump e seus adeptos, mas, também, devido às discordâncias sobre as reivindicações territoriais chinesas. Além disso, as relações entre esses países permeiam as disputas domésticas norte-americanas sobre o comércio mundial, sobre a valorização do dólar e com caráter protecionista - sendo isso ilustrado em março de 2018, na taxação do aço e alumínio pelos EUA, sobre justificativa que os Estados Unidos estava sendo prejudicado no comércio com a China.
Figura 1. Saldo comercial da China com os EUA por grupos de mercadorias por intensidade tecnológica, em US\$ bi (1995-2017).

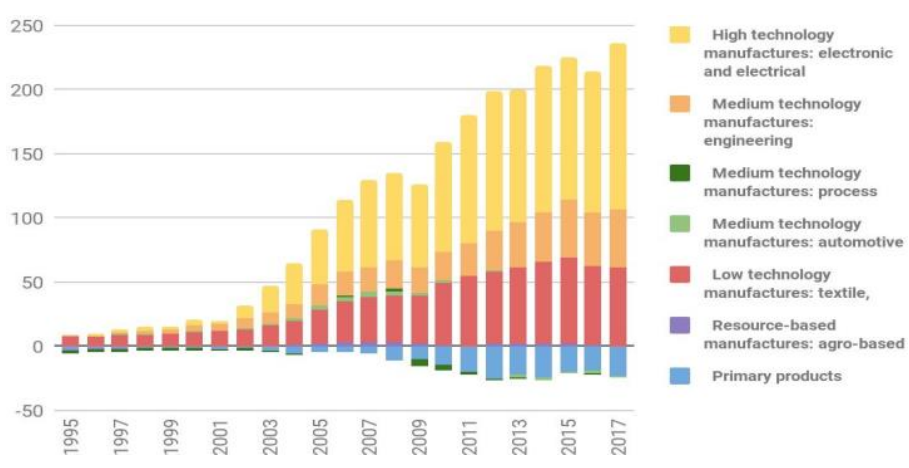

Através do gráfico acima é possível verificar que parte preponderante e crescente do superávit comercial da China com os EUA tem sido baseada em bens de alta intensidade tecnológica. Ou seja, apesar de existir uma relação de complementaridade entre os dois países, nos últimos anos observamos um maior catching-up da economia chinesa, sendo o comércio bilateral mais vantajoso para esta. As manufaturas de alta tecnologia (eletrica e eletronica) que representam o tipo de mercadoria mais importado pelos EUA, apresentou um crescimento expressivo a partir de 2002, sendo atualmente superior a 200 bilhões de dólares. Em contrapartida, os principais produtos que a China importa são produtos primários, sendo de aproximadamente 28 bilhões de dólares no ano de 2017.

\section{Conclusões}

Apesar dos atritos entre os Estados Unidos e a China nos próximos anos, há, também, espaço para uma ligação com maior cooperação. Por certo, o aumento da incerteza e a postura do presidente norte-americano em seus últimos discursos e taxações revelam a possibilidade de uma reconfiguração da relação entre esses países e novos desafios internos para ambos.

BAPTISTA, T. R. A Relação Econômica entre China e Estados Unidos: A interdependência é suficiente para evitar um conflito de poder entre os dois países em um futuro próximo? 2016.

MEDEIROS, Carlos A. A China como um Duplo Polo na Economia Mundial e a Recentralização da Economia Asiática. Revista de Economia Política, v. 26, n. 3 (103), p. 381-400, 2007. 